\title{
Antimicrobial disinfectants and sanitizers: An effective tool for breaking the circle of pandemic disease
}

\author{
Nur Izyan Wan Azelee ${ }^{1,2 *}$, Hesham El-Enshasy, ${ }^{1,2,3}$, Daniel Joe Dailin ${ }^{1,2}$, Nor Hasmaliana Abdul Manas ${ }^{1}$, \\ Roslinda Abd Malek², Mohd Akmali Mokhter ${ }^{3}$, Nurrulhidayah Salamun ${ }^{3}$, Roshanida A. Rahman ${ }^{2}$ \\ ${ }^{1}$ Institute of Bioproduct Development (IBD), Universiti Teknologi Malaysia, 81310, UTM Skudai, Johor, Malaysia \\ ${ }^{2}$ School of Chemical and Energy Engineering, Faculty of Engineering, Universiti Teknologi Malaysia, 81310 UTM Skudai, \\ Johor, Malaysia \\ ${ }^{3}$ Bioprocess Development Department, City for Scientific Research and Technology Applications (CSAT), New Burg Al \\ Arab, Alexandria, Egypt \\ ${ }^{4}$ Department of Chemistry, Faculty of Science, Universiti Teknologi Malaysia, 81310, UTM Skudai, Johor, Malaysia
}

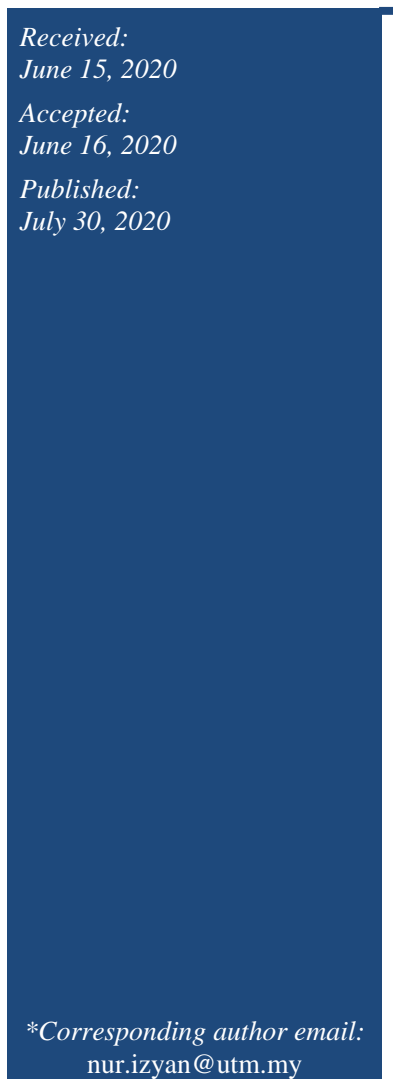

\section{Abstract}

The recent outbreak of Covid-19 pandemic has triggered the world in finding and developing efficient disinfectants and sanitizers. This deadly contagious virus has urged all scientist to study the natural characteristic of the virus and thus, to be able to produce the suitable antiviral drug. As developing vaccine is long time-consuming process, the development of disinfectants and sanitizers are necessary to reduce the spread of this pandemic disease. Many types and version of these products have developed and marketed. Several issues, such as the high percentage of alcohol, the high flammability of the product, and many more have arisen. This review provides a comprehensive overview on the type of chemicals used as antimicrobial in general and antiviral in specific agents. In addition, it also discusses the chemical and herbal formulations, factors affecting the performance of antimicrobial agents, the safety precautions, and the future trend of sanitizers and disinfectants. Ultimately, the choice for the best disinfectants and sanitizers formulation would depend on the sensitivity of the surfaces regardless of on skin or other surface materials.

Keywords: Sanitizer, Disinfectant, Pandemic, Antimicrobial, Antiviral

\section{How to cite this:}

Azelee NIW, El-Enshasy H, Dailin DJ, Manas NHA, Malek RA, Mokhter MA, Salamun N and Rahman RA, 2020. Antimicrobial disinfectants and sanitizers: An effective tool for breaking the circle of pandemic disease. Asian J. Agric. Biol. 8(3): 348-367. DOI: https://doi.org/10.35495/ajab.2020.06.355

This is an Open Access article distributed under the terms of the Creative Commons Attribution 3.0 License. (https://creativecommons.org/licenses/by/3.0), which permits unrestricted use, distribution, and reproduction in any medium, provided the original work is properly cited.

\section{Introduction}

A large scale of infectious disease outbreaks and illnesses which arise from disease-carrying pathogens has and will always be of great concern. The effect of these outbreaks will create a significant economic, social, and political disruption and critical fatality cases (Ogunsona et al., 2020). Throughout these years, several transmissible diseases has already been put to an end. Nonetheless, a few diseases have resurged, and recently we are facing a disease caused by novel coronavirus called COVID- 
19, which the World Health Organization (WHO) has already declared as a pandemic. A pandemic is declared when there is a rapid spread of a disease across a particular region and usually affecting a large number of people. When a pandemic becomes acute, public health will focus on keeping the spread of disease to a minimum. Pharmaceutical approaches such as developing vaccines and antiviral agents as well as non-pharmaceutical approaches such as selfquarantine, proper personal hygiene, isolation and social distancing will be applied to reduce a pandemic spread (Liu et al., 2016; Mitchell et al., 2011).

Since the production capacity of the vaccine on a global scale is inadequate and insufficient to supply to all countries, antiviral agents and antimicrobial disinfectants are considered as an effective solution. They are very useful, especially in the early stages of a pandemic. Antimicrobial is a substance that demonstrates the ability to destroy or inhibit the growth of microorganisms and especially pathogenic ones. Disinfectants and sanitizers are used to control pathogens and other microbes on inanimate surfaces and skin. Cleaning followed by disinfecting or sanitizing is necessary steps to ensure surfaces are free from microorganisms as possible. Edmonds et al. (2010) recommended a proper practice of hand hygiene other than washing with water and soap such as hand sanitizers with antimicrobial or alcoholbased to prevent transmission of illness from any infectious pathogens. Some studies indicate that a duration of 20 seconds of hands washing with mild soap and water was more effective than applying a $70 \%$ alcohol hand sanitizer (Charbonneau et al., 2000). It has been reported that promoting proper hand washing will reduce the risk of diarrheal disease in the range between 23 to $40 \%$ and the risk of respiratory infection by 16 to $21 \%$ (Aiello et al., 2008; Rabie and Curtis, 2006). However, when soap and water are not available, hand sanitizers and disinfectants are the best alternatives to reduce infection transmission by inactivating and inhibiting the microorganism's growth.

A wide variety of antimicrobial agents commonly used in hygiene products include alcohol, chlorine derivatives, quaternary ammonium compounds, iodine, parachlorometaxylenol, triclosan and recently peracetic acid (Weber et al., 2007; Wong et al., 2018). The most common hand sanitizers are divided into alcohol-based and alcohol-free sanitizers. Alcohol-based hand sanitizers usually contain ethanol, N-propanol or isopropanol, or a combination of these two chemicals to increase its effectiveness. The main attribute of alcohol in increasing the antimicrobial activity is their aptness to alter the nature qualities and state of proteins. At the moment, most of the hand sanitizers that act as antiseptic contain 60 to $90 \%$ of alcohol composition. While the most common active ingredient contained in an alcohol-free based hand sanitizer is a type of quaternary ammonium which is benzalkonium chloride. It is non-flammable and relatively non-toxic at low concentrations. Therefore, it poses low threat such as accidental ingestion, possibility to start a fire and surface damage. Another potential and efficient chemical disinfectant is peracetic acid which acts as an oxidant that renders the cell inactive by oxidizing the outer cell membranes of microorganisms. A study from Meade and Garvey (2018) revealed that peracetic acid had successfully inactivated all tested microbial strains and thus, showing its potential in preventing nosocomial infections. However, alcoholfree hygiene products have yet to gain interest in the current health market compared to the alcohol-based sanitizers. Most health organizations favoured alcohol-based hygiene products and therefore, perceived as being more credible.

There are some complications and concerns for the extensive use of alcohol-based sanitizers. For example, it does not only effectively destroy many pathogens but also inactivate the beneficial bacteria. Apart from that, it can cause alcohol poisoning if a person purposely or accidentally swallows more than a couple of mouthfuls. Previous studies have found that the ingestion of alcohol, specifically ethanol from hand sanitizers, can induce intoxication and hypoglycemia in children (Gormley et al., 2012). From 2011 until 2015, the American Association of Poison Control Centers (AAPCC) reported to receive more than 80,000 calls regarding hand sanitizer intoxication among children. Therefore, alternative natural resources like herbs, trees, essences, and extracts that contain numerous bioactive products that show antimicrobial effects are vastly studied to replace the alcohol-based sanitizers.

\section{Antiviral and antibacterial formulations and applications Chemical disinfectant formulations}

In general, the majority of the chemical disinfectant contains alcohol in the formulation (mainly ethanol 
and propanol). However, ethanol has greater efficiency for non-enveloped viruses compared to propanols. As reported by WHO, 80\% ethanol concentration as one of the essential medicines for alcohol-based hand rub. Ethanol at concentration 95\% is effective in killing the majority of the clinical viruses, which is suitable to be used during viral pandemic (Kampf, 2018). Virus infection has taken up to $5 \%$ of the diseases related to healthcare. It has also been concluded that the efficiency of using lower alcohol concentration can be enhanced by the addition of acids into the solvent mixture. However, alcohols such as ethanol and propanol may have adverse effects on sensitive skin such as skin irritation (Joshi et al., 2008). Hence, the formulation of an antiviral hand disinfectant must be based on these two critical criteria, which are specified on the most common viruses that exist in a particular condition and also user acceptability to be used frequently under certain conditions. Table 1 shows the percentage of ethanol for killing several studied viruses. It shows that different type of viruses has different resistance strength towards ethanol.

There is also virus species which still can survive at high ethanol concentration $(95 \%)$ such as the Hepatitis A virus (WoIff et al., 2001) and parvovirus (van Engelenburg et al., 2002). In some instances, the addition of acids such as phosphoric acid, peracetic acid, and citric acid into the ethanol formulation can increase the virucidal activity for the highly resistant viruses. The preferred formulations with virucidal activity for human medicine must cover both the enveloped and non-enveloped viruses (Kampf, 2018).

However, as alcohol is known to evaporate quickly, the hand sanitizer needs to be applied more frequently on the skin. The frequent apply on the skin could result in skin irritation, skin dryness, enlargement of the pores, and thus making sensitives skin more susceptible to infection. Additionally, this causes troublesome, especially to those who are dealing or being exposed to microbes in their everyday life, such as healthcare professionals, researchers, and many others. This scenario has triggered Revellame and Holmes (2019) to formulate a special hand sanitizer with prolonged effectiveness and, at the same time avoiding damage to the skin. They have come out with a skin lotion sanitizer where the ingredients used protect the skin's texture with more control released of the active ingredients. The product invented was claimed to be having bifunction as moisturizer and sanitizer. Nevertheless, sanitizers with moisturizing skin protecting are unstable and the formulation tend to be separated over prolonged time (Berland, 2019). This may also cause the sanitizer to feel greasy when applied on the skin, which is not a pleasant texture. To overcome this problem, the manufacturer typically will add emulsifiers to incorporate the moisturizer with the formulation. However, most of the emulsifier is not friendly to the skin.

Besides alcohol, other types of chemicals, such as hydrogen peroxide and peracetic acid, are also being used as disinfectants. These chemicals usually are being used in bleaching agents either in solution or powder-based. However, these chemicals are very corrosive with additional pungent smell resulting in the damages to the equipment. Additionally, the bad pungent smell from the chemicals is far beyond what people could bear when it is applied in a large surface area. The high concentration of these chemicals is also hazardous to the eye and skin when being in contact. Qian (2019) has invented a new disinfectant formulation having low toxicity, negligible pungent odour, and less corrosive effect. Optimization was done based on the highest efficiency of the disinfectant in killing the microorganism as well as having a tolerant smell. The formulation has shown excellent disinfecting efficacies, which could kill up to $99.999 \%$ of the vegetative cells (Escherichia Coli, Staphylococcus aureus), virus (Poliovirus, Influenza H1N1) and spore (Bacillus subtilis, Aspergillus flavus Spore). The formulation invented by Qian claimed to be suitable for disinfecting homes and public areas. 
Nur Izyan Wan Azelee et al.

Table-1. Percentage of ethanol for killing several studied viruses

\begin{tabular}{|c|c|c|c|}
\hline Category & Virus & Ethanol concentration & Reference \\
\hline \multirow{3}{*}{ Enveloped viruses } & SARS coronavirus & $42.6 \%$ & (Siddharta et al., 2017) \\
\cline { 2 - 4 } & HCV & $73.6 \%$ & (Steinmann et al., 2010) \\
\hline \multirow{5}{*}{ Non-enveloped viruses } & Adenovirus & $70 \%$ & (Kampf et al., 2013) \\
\cline { 2 - 4 } & Rotavirus & $85 \%$ & (Macinga et al., 2008) \\
\cline { 2 - 4 } & Norovirus & $85 \%$ & (Steinmann et al., 2010) \\
\cline { 2 - 4 } & Coxsackie virus & $72.5 \%$ & (Iwasawa et al., 2012) \\
\cline { 2 - 4 } & Foot-and-mouth disease virus & $72.5 \%+$ acids & (Kampf et al., 20015) \\
\cline { 2 - 4 } & Polyomavirus & $85 \%$ & \\
\hline
\end{tabular}

Table-2. Chemical-based hand sanitizer formulation

\begin{tabular}{|c|c|c|c|c|}
\hline Base & Component & Concentration & Function & Reference \\
\hline $\begin{array}{l}\text { Lotion } \\
\text { (oil-in- } \\
\text { water } \\
\text { emulsion) }\end{array}$ & $\begin{array}{c}\text { Benzalkonium Chloride } \\
\text { Tri-n-Butyl Phosphate } \\
\text { Methyl Paraben } \\
\text { Propyl Paraben } \\
\text { Citricidal } \\
\text { d- } \alpha \text {-Tocopherol Acetate } \\
\text { Waxy Corn Starch } \\
\text { Xanthan } \\
\text { Pectin } \\
\text { Soy Bean Oil } \\
\text { Petrolatum } \\
\text { Deionized Water }\end{array}$ & \begin{tabular}{|l|}
$0.13 \%$ \\
$0.15 \%$ \\
$0.10 \%$ \\
$0.10 \%$ \\
$0.15 \%$ \\
$0.06 \%$ \\
$6.33 \%$ \\
$0.38 \%$ \\
$0.76 \%$ \\
$1.69 \%$ \\
$0.84 \%$ \\
balance
\end{tabular} & $\begin{array}{c}\text { Active ingredient } \\
\text { Anti-foam } \\
\text { Preservative } \\
\text { Preservative } \\
\text { Antioxidant } \\
\text { Vitamin E } \\
\text { Emulsifier } \\
\text { Thickener } \\
\text { Thickener } \\
\text { Oil-phase } \\
\text { Skin protectant } \\
\text { Water-phase }\end{array}$ & $\begin{array}{l}\text { (Revellame and } \\
\text { Holmes, 2019) }\end{array}$ \\
\hline Alcohol & $\begin{array}{c}\text { Ethanol } \\
\text { Isopropanol } \\
\text { PLANELL } \\
\text { ZEMEA } \\
\text { Water } \\
\end{array}$ & $\begin{array}{c}7.2 \mathrm{~g} \\
0.8 \mathrm{~g} \\
50 \mathrm{mg} \\
100 \mathrm{mg} \\
1.85 \mathrm{~g}\end{array}$ & $\begin{array}{c}\text { Antimicrobial agent } \\
\text { Antimicrobial agent } \\
\text { Moisturizer } \\
\text { Solubilizer } \\
\text { Medium } \\
\end{array}$ & (Berland, 2019) \\
\hline Water & $\begin{array}{c}\text { Hydrogen peroxide } \\
\text { Peracetic acid } \\
\text { Tetrabutylammonium } \\
\text { hydroxide } \\
\text { Cetyltrimethylammonium } \\
\text { bromide } \\
\text { Sodium dodecyl sulfate } \\
\text { Sodium hydroxide } \\
\text { Sodium pyrophosphate } \\
\text { Water }\end{array}$ & $\begin{array}{c}0.1-6 \% \\
0.01-0.6 \% \\
0.01-2 \% \\
0.01-2 \% \\
0.01-1 \% \\
0.1-3 \% \\
0-1 \% \\
90-96 \%\end{array}$ & $\begin{array}{c}\text { Antimicrobial agent } \\
\text { Antimicrobial agent } \\
\text { Ion-pair reagent } \\
\text { Phase transfer catalyst } \\
\text { reagents } \\
\text { Surfactant } \\
\text { Base } \\
\text { Stabilizers } \\
\text { Water-phase }\end{array}$ & (Qian, 2019) \\
\hline Water & $\begin{array}{c}\text { Calcium hydroxide } \\
\text { Sodium hypochlorite } \\
\text { Water }\end{array}$ & $\begin{array}{c}0.12-0.18 \% \\
2.5 \% \\
97 \% \\
\end{array}$ & $\begin{array}{c}\text { Antimicrobial agent } \\
\text { Antimicrobial agent } \\
\text { Water-phase } \\
\end{array}$ & $\begin{array}{c}\text { (Martin and } \\
\text { Pardiak, 2019) }\end{array}$ \\
\hline
\end{tabular}




\section{Disinfectant formulations with natural/herbal extract \\ Antibacterial hand sanitizer}

Hand sanitizer has been developed as a practical product to clean the hands from bacteria without the need for water and soap. Hand sanitizer has become a more demanding and essential product nowadays due to the Coronavirus (Covid19), which has triggered the whole world starting from the end of 2019. In Indonesia, a group of researchers has successfully formulated a gel hand sanitizer with an antibacterial effect from the extract of two types of seaweed species. Eucheuma spinosum and Eucheuma cotonii, which were obtained from the Wakatobi Island situated in Southeast Sulawesi, were extracted using the maceration method with methanol was used as the extraction solvent (Akib et al., 2019). Methanol was chosen as it can dissolve the polar and non-polar metabolites. The active ingredients in both Eucheuma species contain flavonoid, triterpenoid, steroid, and alkaloid, which is believed to act as the antibacterial agent (Andriani et al., 2015). Eucheuma extract at $4 \%$ concentration, has successfully shown the antibacterial effect on Escherichia coli (Gramnegative) and Staphylococcus aureus (Grampositive), which are the most common bacteria exist on human skin.

\section{Antibacterial foot sanitizer}

The bad aroma from the foot of a particular person comes from the growth and action of bacteria in the high moisture condition, which comes from the sweat. Staphylococcus epidermis is one of the bacteria which degrade leucine, a vital amino acid involved in protein synthesis and several metabolic functions. The formation of isovaleric acid, which resulted from leucine degradation, is the main factor causing the unpleasant smell from the foot (Ara et al., 2006). Joko and Riyanta (2019) have developed foot sanitizer spray containing coffee beans and ginger extract with ethanol as the base. The formula has been optimized so that it can be able to instantly (< 30 minutes) kill the bacteria on the surface of the skin. According to the Center for Disease Control (CDC), the content of alcohol in sanitizers must be in the range of $60-90 \%$ for an excellent antibacterial effect. It has also been reported that the extract of coffee beans in a foot sanitizer helps in deodorizing the lousy smell (Riyanta and Febriyanti, 2018). Coffee has a low moisture content $(<12 \%)$ and can function as good adsorbent, which is similar to activated carbon (Aldi Budi and Nurniswati, 2016). Meanwhile, the content of flavonoid and phenol in ginger can act as an antibacterial agent. These active ingredients play a role in degrading the bacteria cell wall resulting in cell lysis (Pelczar et al., 1993). The study by Joko and Riyanta (2019) has proved that formulations containing the highest ginger extract resulted in higher efficiency for the antibacterial.

\section{Herbal Disinfectant}

Pandya et al., (2017) have carried out a study on the effect of different herbal formulations against two types of pathogenic bacteria (Staphylococcus aureus and Escherichia coli). Different herbal formulations were developed using four types of herbal, which is soapnut seed, neem seeds, balanites seeds, and harde seeds. It was investigated that the different content of active ingredients such as phenolic compounds, triterpenoids, steroids, valavinoids, carotenoids, ketones and tetra-triterpenoids and azadirachtin in all the seeds had contributed to the good antimicrobial effect (Saradhajyothi and Subbarao, 2011). Table 3 summarizes several sanitizer formulations incorporating some natural extracts.

\section{Factors affecting the performance of antimicrobial agents}

The choice of disinfectant for surface decontamination should take into account the ability of the disinfectant to kill a wide range of pathogenic microorganisms. In addition, the emergence of resistant microorganisms has made disinfection challenging, especially in healthcare facilities. The increasing usage of household disinfectants raises the occurrence of improper use, such as wrong concentration in the formulation that leads to microorganisms adaptation to the biocide active ingredient (Smith et al., 2016). Methicillin-resistant Staphylococcus aureus, vancomycin-resistant Enterococci, Candida auris, and Candida albicans are among common resistant microorganisms in healthcare facilities (Deshpande et al., 2014). Table 4 summarises different disinfectant active ingredients and their efficacy in killing various kinds of microorganisms, including resistant microorganisms. The germicidal efficacy of disinfectant is commonly measured by the reduction of microbial activity (in $\log 10$ unit). The reduction of microbial activity of at least $3-\log 10$ is likely to be considered clinically effective (Rutala and Weber, 2019). Alcohol-based disinfectant has biocidal activity over a wide range of 
microorganisms, including viruses, bacteria, and fungus. However, it has a low sporicidal effect. Chlorine-based disinfectant such as sodium hypochlorite was effective against spore-forming microorganisms such as Clostridium difficile. The mixture of peracetic acid/hydrogen peroxide was also effective as a disinfectant to kill spores.

Sodium hypochlorite is commonly used as a sporicidal agent. However, due to its corrosive and irritating properties, peracetic acid (or peroxyacetic acid) has emerged as an alternative sporicidal agent as it is less corrosive and less irritating (Cadnum et al., 2017).

The sporicidal activity of peracetic acid/hydrogen peroxide-based disinfectant has shown as effective as bleach for in vitro killing of common healthcareassociated pathogens such as $C$. difficile spores, as well as methicillin-resistant $S$. aureus, and vancomycin-resistant Enterococci (Deshpande et al., 2014). Peracetic acid has also shown effective against $C$. auris and $C$. albicans fungus. However, it was reported that peracetic acid could reduce its efficacy after three weeks of storage (Deshpande et al., 2014). There was evidence of increased $C$. difficile infection incidence due to defective peracetic acid disinfectant solution. As suggested by (Cadnum et al., 2017), it is essential to evaluate the efficacy of liquid disinfectant used, especially in healthcare facilities before use. It was suggested to activate peracetic acid on-site just before use and use the activated solution within its specified period (Deshpande et al., 2014). Pathogens have different times of persistence on inanimate surfaces. Time of exposure is an essential factor in choosing or formulating disinfectant. Disinfection time varies depending on the type of organisms, and it has a direct correlation with the concentration of its active ingredient. In general, alcohol-based disinfectants are effective at $70 \%$ concentration with an exposure time of 30 seconds to 5 minutes. Mechanism of biocide by alcohol was explained by (Aboualizadeh et al., 2017) that involves molecular denaturation of protein and membrane disruption. These biochemical changes were observed in cytoplasmic membrane protein and phosphate groups of the bacterial cell wall. Because alcohol evaporates quickly, $30 \%$ of aqueous content gives enough time for alcohol to perform the molecular damages to cells. Sodium hypochlorite or household bleach is the most common disinfectant used owing to its efficiency at low concentration, a short period of exposure, and longer shelf life. On average, $0.5 \%$ sodium hypochlorite is competent enough to kill a wide range of microorganisms at exposure time between $30 \mathrm{~s}$ to $15 \mathrm{~min}$. Sodium hypochlorite causes protein denaturation and disrupts lipid membranes and phosphate groups, resulting in damage to the phospholipid bilayers in the membrane of the cell (Aboualizadeh et al., 2017). Peracetic acid and hydrogen peroxide are as efficient as sodium hypochlorite in terms of efficiency as a disinfectant, but it has a shorter shelf life. Its noncorrosive property makes it an excellent alternative to sodium hypochlorite.

Table-3. Natural extract sanitizer formulations

\begin{tabular}{|c|c|c|c|c|}
\hline Purpose & Component & Concentration & Function & Reference \\
\hline \multirow{9}{*}{ Hand sanitizer } & Eucheuma extract & $4 \%$ & Active ingredient & \multirow{9}{*}{ (Akib et al., 2019) } \\
\hline & Carbopol & $0.5 \%$ & Gel formation & \\
\hline & Triethanolamine & 5 drops & Neutralizer & \\
\hline & Propylene glycol & $15 \%$ & Moisturizer & \\
\hline & Methyl paraben & $0.2 \%$ & Preservative & \\
\hline & Green tea fragrance & 2 drops & Aroma & \\
\hline & Fast green color & 1 drop & Colouring & \\
\hline & Alcohol & $15 \%$ & Evaporation aid & \\
\hline & Distilled water & $65.3 \%$ & Solvent & \\
\hline \multirow{5}{*}{ Foot sanitizer } & Ginger extract & $45 \%$ & Active ingredient & \multirow{5}{*}{$\begin{array}{c}\text { (Santoso and } \\
\text { Riyanta, 2019) }\end{array}$} \\
\hline & Coffee bean extract & $25 \%$ & Active ingredient & \\
\hline & Glycerine & $10 \%$ & Moisturizer & \\
\hline & Methyl paraben & $0.2 \%$ & Preservative & \\
\hline & Alcohol (70\%) & $50 \mathrm{~mL}$ & Evaporation aid & \\
\hline
\end{tabular}


Nur Izyan Wan Azelee et al.

Table-4. Common disinfectants and its efficacy in killing various types of microorganism

\begin{tabular}{|c|c|c|c|c|c|}
\hline Disinfectant & Pathogen & Concentration & $\begin{array}{l}\text { Exposure } \\
\text { time }\end{array}$ & $\begin{array}{c}\text { Reduction of } \\
\text { infectivity } \\
(\log 10) \\
\end{array}$ & Reference \\
\hline \multirow{4}{*}{ Ethanol } & Coronaviruses (virus) & $70-95 \%$ & $30 \mathrm{~s}-10 \mathrm{~min}$ & $>3.3-\geq 5.5$ & $\begin{array}{l}\text { (Kampf et al., } \\
2020)\end{array}$ \\
\hline & $\begin{array}{l}\text { Candida auris and Candida } \\
\text { albicans (yeast) }\end{array}$ & $70 \%$ & $1 \mathrm{~min}$ & $2.5-4.0$ & $\begin{array}{c}\text { (Rutala and Weber, } \\
\text { 2019) } \\
\end{array}$ \\
\hline & $\begin{array}{l}\text { Methicillin-resistant } \\
\text { Staphylococcus aureus } \\
\text { (bacteria) }\end{array}$ & $70 \%$ & - & $\begin{array}{l}\text { (0 CFU after } \\
\text { disinfection) }\end{array}$ & $\begin{array}{l}\text { (Aboualizadeh et } \\
\text { al., 2017) }\end{array}$ \\
\hline & Zaire ebolavirus (virus) & $70 \%$ & $2.5 \mathrm{~min}$ & 0 & (Cook et al., 2016) \\
\hline \multirow{3}{*}{ 2-Propanol } & Corona viruses (virus) & $50-100 \%$ & $30 \mathrm{~s}-10 \mathrm{~min}$ & $\geq 4.0-\geq 3.3$ & $\begin{array}{c}\text { (Kampf et al., } \\
\text { 2020) }\end{array}$ \\
\hline & $\begin{array}{l}\text { Candida auris and Candida } \\
\text { albicans (yeast) }\end{array}$ & $70 \%$ & $1 \mathrm{~min}$ & $3.8-4.1$ & $\begin{array}{c}\text { (Rutala and Weber, } \\
\text { 2019) } \\
\end{array}$ \\
\hline & $\begin{array}{l}\text { Methicillin-resistant } \\
\text { Staphylococcus aureus } \\
\text { (bacteria) }\end{array}$ & $70 \%$ & - & $\begin{array}{l}\text { (0 CFU after } \\
\text { disinfection) }\end{array}$ & $\begin{array}{l}\text { (Aboualizadeh et } \\
\text { al., 2017) }\end{array}$ \\
\hline \multirow{10}{*}{$\begin{array}{l}\text { Sodium } \\
\text { hypochlorite }\end{array}$} & Corona viruses (virus) & $0.001-0.21 \%$ & $30 \mathrm{~s}-10 \mathrm{~min}$ & $0.3-\geq 4.0$ & $\begin{array}{l}\text { (Kampf et al., } \\
\text { 2020) }\end{array}$ \\
\hline & Clostridium difficile (spore) & $0.615 \%$ & $3-10 \mathrm{~min}$ & $2.37->4.36$ & \multirow{3}{*}{$\begin{array}{c}\text { (Deshpande et al., } \\
\text { 2014) }\end{array}$} \\
\hline & $\begin{array}{l}\text { Methicillin-resistant } \\
\text { Staphylococcus aureus } \\
\text { (bacteria) }\end{array}$ & $0.615 \%$ & $3-10 \min$ & $3.93->6.40$ & \\
\hline & $\begin{array}{l}\text { Vancomycin-resistant } \\
\text { Enterococci (bacteria) }\end{array}$ & $0.615 \%$ & $3-10 \mathrm{~min}$ & $5.36->6.58$ & \\
\hline & $\begin{array}{l}\text { Candida auris \& Candida } \\
\text { albicans (yeast) }\end{array}$ & $0.525 \%$ & $1 \mathrm{~min}$ & $4.0-4.1$ & $\begin{array}{c}\text { (Rutala and Weber, } \\
\text { 2019) }\end{array}$ \\
\hline & $\begin{array}{l}\text { Methicillin-resistant } \\
\text { Staphylococcus aureus } \\
\text { (bacteria) }\end{array}$ & $5 \%$ & - & 0 & $\begin{array}{l}\text { (Aboualizadeh et } \\
\text { al., 2017) }\end{array}$ \\
\hline & Zaire ebolavirus (virus) & $0.5 \%$ & $5 \mathrm{~min}$ & 0 & (Cook et al., 2016) \\
\hline & Ebola surrogate Phi6 (virus) & $0.5 \%$ & $15 \mathrm{~min}$ & 3.1 & (Gallandat et al., \\
\hline & Esherichia coli (bacteria) & $0.5 \%$ & $15 \mathrm{~min}$ & 5.9 & 2017) \\
\hline & Adenovirus D (virus) & $0.1 \%$ & $30 \mathrm{~s}-1 \mathrm{~min}$ & $>4.0$ & $\begin{array}{c}\text { (Hashizume et al., } \\
\text { 2019) }\end{array}$ \\
\hline \multirow{3}{*}{$\begin{array}{l}\text { Peracetic } \\
\text { acid/hydrogen } \\
\text { Peroxide } \\
\text { (OxyCide, Ecolab) }\end{array}$} & Clostridium difficile (spores) & - & $3-10 \mathrm{~min}$ & $3.76-4.6$ & \multirow{3}{*}{$\begin{array}{l}\text { (Deshpande et al., } \\
\text { 2014) }\end{array}$} \\
\hline & $\begin{array}{l}\text { Methicillin-resistant } \\
\text { Staphylococcus aureus } \\
\text { (bacteria) }\end{array}$ & - & $3-10 \mathrm{~min}$ & $>4.78->6.4$ & \\
\hline & $\begin{array}{l}\text { Vancomycin-resistant } \\
\text { Enterococci (bacteria) }\end{array}$ & - & $3-10 \mathrm{~min}$ & $5.42->6.58$ & \\
\hline Peracetic acid & $\begin{array}{l}\text { Candida auris \& Candida } \\
\text { albicans (yeast) }\end{array}$ & $0.2 \%$ & $1 \mathrm{~min}$ & 4.1 & $\begin{array}{l}\text { (Rutala and Weber, } \\
\text { 2019) }\end{array}$ \\
\hline \multirow{2}{*}{$\begin{array}{l}\text { Hydrogen } \\
\text { peroxide }\end{array}$} & Corona viruses (virus) & $0.5 \%$ & $1 \mathrm{~min}$ & $>4.0$ & $\begin{array}{c}\text { (Kampf et al., } \\
2020) \\
\end{array}$ \\
\hline & $\begin{array}{l}\text { Candida auris \& Candida } \\
\text { albicans (yeast) }\end{array}$ & $1.4-3 \%$ & $1 \mathrm{~min}$ & $1.4-4.1$ & $\begin{array}{c}\text { (Rutala and Weber, } \\
\text { 2019) } \\
\end{array}$ \\
\hline \multirow{2}{*}{ Glutaraldehyde } & Corona viruses (virus) & $0.5-2.5 \%$ & $2-5 \min$ & $>4.0$ & $\begin{array}{c}\text { (Kampf et al., } \\
\text { 2020) }\end{array}$ \\
\hline & $\begin{array}{l}\text { Candida auris \& Candida } \\
\text { albicans (yeast) }\end{array}$ & $2.4 \%$ & $1 \mathrm{~min}$ & 4.1 & $\begin{array}{c}\text { (Rutala and Weber, } \\
\text { 2019) }\end{array}$ \\
\hline \multirow{2}{*}{ Povidone/iodine } & Corona viruses (virus) & $0.23-7.5 \%$ & $15 \mathrm{~s}-1 \mathrm{~min}$ & $>3.8->5.0$ & $\begin{array}{c}\text { (Kampf et al., } \\
2020) \\
\end{array}$ \\
\hline & $\begin{array}{l}\text { Candida auris \& Candida } \\
\text { albicans (yeast) }\end{array}$ & $10 \% / 1 \%$ & $1 \mathrm{~min}$ & $2.3-2.5$ & $\begin{array}{c}\text { (Rutala and Weber, } \\
\text { 2019) } \\
\end{array}$ \\
\hline
\end{tabular}


Nur Izyan Wan Azelee et al.

\begin{tabular}{|c|c|c|c|c|c|}
\hline \multirow[b]{2}{*}{ Triclosan } & $\begin{array}{l}\text { Candida auris \& Candida } \\
\text { albicans (yeast) }\end{array}$ & $0.5 \%$ & $1 \mathrm{~min}$ & $1.4-1.7$ & \begin{tabular}{|c} 
(Rutala and Weber, \\
2019)
\end{tabular} \\
\hline & $\begin{array}{l}\text { Methicillin-resistant } \\
\text { Staphylococcus aureus } \\
\text { (bacteria) }\end{array}$ & $1 \%$ & & & $\begin{array}{l}\text { (Aboualizadeh et } \\
\text { al., 2017) }\end{array}$ \\
\hline \multirow{2}{*}{$\begin{array}{l}\text { Chlorhexidine } \\
\text { digluconate }\end{array}$} & Corona viruses (virus) & $0.02 \%$ & $10 \mathrm{~min}$ & $0.3-0.8$ & $\begin{array}{c}\text { (Kampf et al., } \\
2020)\end{array}$ \\
\hline & $\begin{array}{l}\text { Candida auris and Candida } \\
\text { albicans (yeast) }\end{array}$ & $4 \%$ & $1 \mathrm{~min}$ & $1.9-3.5$ & $\begin{array}{c}\text { (Rutala and Weber, } \\
\text { 2019) }\end{array}$ \\
\hline Formaldehyde & Corona viruses (virus) & $0.009-1 \%$ & $\begin{array}{c}2 \min -24 \\
\text { hour }\end{array}$ & $>3.0->4.0$ & \begin{tabular}{|c|} 
(Kampf et al., \\
$2020)$ \\
\end{tabular} \\
\hline Chloroxylenol & $\begin{array}{l}\text { Candida auris \& Candida } \\
\text { albicans (yeast) }\end{array}$ & $1 \%$ & $1 \mathrm{~min}$ & $2.8-3.9$ & $\begin{array}{c}\text { (Rutala and Weber, } \\
\text { 2019) } \\
\end{array}$ \\
\hline $\begin{array}{l}\text { Benzalkonium } \\
\text { chloride }\end{array}$ & Corona viruses (virus) & $0.00175-0.2 \%$ & $\begin{array}{c}10 \text { min }-3 \\
\text { days }\end{array}$ & $0.0-3.7$ & \begin{tabular}{|c|} 
(Kampf et al., \\
$2020)$
\end{tabular} \\
\hline $\begin{array}{l}\text { Didecyldimethyl } \\
\text { ammonium } \\
\text { chloride } \\
\end{array}$ & Corona viruses (virus) & $0.0025 \%$ & 3 days & $>4.0$ & $\begin{array}{l}\text { (Kampf et al., } \\
\text { 2020) }\end{array}$ \\
\hline $\begin{array}{l}\text { Potassium } \\
\text { peroxymonosulfate }\end{array}$ & Adenovirus D (virus) & $1 \%$ & $30 \mathrm{~s}-1 \mathrm{~min}$ & $>4.0$ & $\begin{array}{c}\text { (Hashizume et al., } \\
\text { 2019) }\end{array}$ \\
\hline
\end{tabular}

\section{Chemical versus herbal disinfectants}

On the market, there are two types of disinfectants. One is classified as a chemical disinfectant, and one is a herbal based disinfectant. Most chemical disinfectants contain alcohol and usually brings adverse effects, which include allergic reactions and pathogens resistance. Antimicrobial disinfectants and sanitizers are preparations containing both a detergent and antiseptics or disinfectants with antibacterial activity, such as alcohols, triclosan, chlorhexidine gluconate (CHG), para-chloro-metaxylenol (PCMX), hexachlorophene, iodine, and iodophors. Another group of instant hand products, the alcohol-free hand sanitizers such as compounds based on povidone-iodine, triclosan, or quaternary ammonium, has also attracted growing interest. Alcohol-based hand rubs (ABHRs) is the most widely used hand sanitizers. They may contain additional active ingredients such as quaternary ammonium compounds (QAC), povidone-iodine, triclosan or chlorhexidine and glycerol that mainly serve to contribute to the efficacy of formulations (Choi and Oh, 2019; Fisher, 2003; Gold and Avva, 2020; Romanowski et al., 2019; WHO, 2009; Zandiyeh and Roshanaei, 2015).

Today herbal disinfections as an alternative and environmentally friendly approach are presented in the industrial sector. Many researchers from various industries are looking for new antimicrobials to produce phytochemicals (allelochemicals) (Saxena et al., 2013).
These substances could be used for disinfection, antiseptics, toothpaste, and chemotherapy. Natural saponifiers are known to be a good source for the formulation of disinfectants. It is both an additive and a component because of the reporting of the antimicrobial properties of plants that contain saponin (Khan et al., 2018; Mujeeb et al., 2014). Ironically, many biocides may be used alone or in combination with commercial products, which differ according to interaction with microorganisms.

\section{Chemicals (agents/biocide) for hand sanitizers and disinfectant \\ Alcohols}

Alcohol-based hand rub (ABHR) for hand wash described as "fluid, gel, or any end product intended to be applied in the hands to promote or temporarily suppress/kill the growth of microorganisms, according to the World Health Organisation (Gold and Avva, 2020; WHO, 2009). Preparations of ABHR include one or more alcohol sources, other active substances, humectants, and the factors influencing the antibacterial effectiveness, such as type, concentration, applied volume, and duration of contact with an antiseptic (Zandiyeh and Roshanaei, 2015). Many hand antiseptic products accommodate ethanol, propan-2-ol (isopropanol, alcohol isopropyl), propan-1-ol (n-propanol, alcohol propane), or other variants. Figure 1 illustrates the molecular structure of alcohol and its derivatives. 

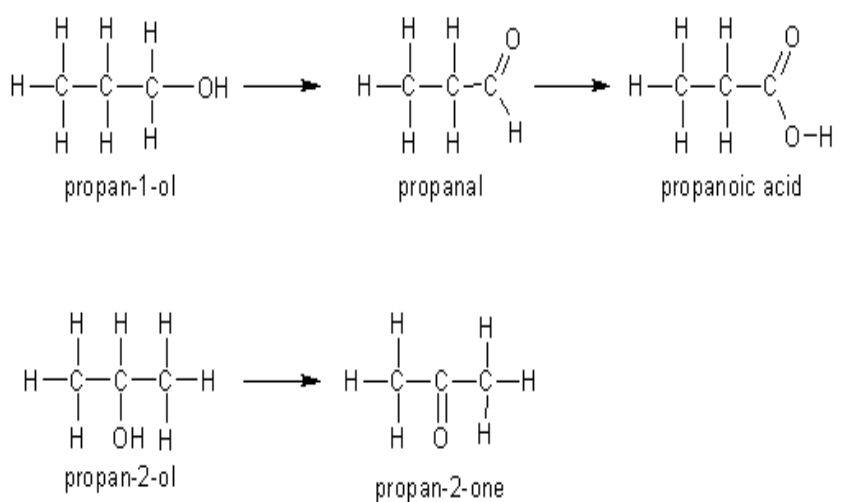

Figure-1. Alcohols and its derivatives

\section{Quaternary ammonium compounds (QAC)}

QAC has a broad spectrum of action against microorganisms, including gram-positive bacteria, gram-negative bacteria, Mycobacterium, Bacillus spores, Listeria monocytogens, protozoa, fungus and group of viruses (Enteroviruses, Rotavirus, Norovirus, Influenza virus and Hepatitis A virus (Gerba, 2015). QACs are target to damage the membranes, connect mostly at the cytoplasmic plasma membrane of bacteria or yeast, the existence of hydrophobicity let this biocide against lipidcontaining viruses and interact with intracellular targets and attach to DNA (Ji et al., 2017). QACs are typically widely implemented in surface hygiene, such as floors, furniture, walls, and excellent wetting agents. QAC biocide based hand sanitizers often use safely as a non-flammable and friendly user if intentional consumption compared to alcohol-based hand sanitizer.

\section{Chlorhexidine gluconate (CHG)}

In general, CHG exists as acetate (diacetate), gluconate, and hydrochloride (salts) (Kampf and Kramer, 2004). As chlorhexidine is a cation, natural soap, nonionic anions, and nonionic hand creams minimize its effectiveness (Nicolay, 2006). A variety of personal hygiene preparations have included CHG. This chemical is used in different concentrations in antiseptic solutions like hibiscrub and hibisol, as well as other materials, such as dental washing. Aqueous and detergent containing $0.5 \%$ as well as $0.75 \%$ chlorhexidine seem to be more efficient than soap, and less efficient than $4 \%$ chlorhexidine gluconate (Nicolay, 2006). CHG is also the most broadly used biocide in hand sanitizer and oral products due to its broad range effectiveness, minimal toxicity, and excellent soft-tissue efficacy ad safety. It is used topically and intra-corporeally as an irrigating dental fluid in surgical preparation. Presently, Chlorhexidine FDA is permitted for intravenous catheter coatings, and human testing and has proven its efficiency and effectiveness in reducing catheter-related infection (Riool, 2017).

\section{Chloroxylenol (PCMX)}

Chloroxylenol (PCMX) is a halogen-substitute phenolic agent that is commonly used as a preservative and also as an active ingredient in topical antiseptic drugs (Yost et al., 2016) and non living surfaces (Choi and Oh, 2019).

\section{Hexachlorophene}

Hexachlorophene is a bisphenol antiseptic agent comprising of two phenolic groups and three moieties, including chlorine with bacteriostatic activity. The end product formulation comprising $3 \%$ hexachlorophene are mostly used as sanitizers in hospitals in the 1950s and 1960s, as surgical scrubs, and new-born baby baths (WHO, 2009). Hexachlorophene is widely used in soaps, creams, aerosol deodorants, skin treatments and bacteriostatically active in the treatment of grampositive bacteria, but less effective in the treatment of gram-negative microorganisms, fungi, and mycobacteria (Will and Varsel, 2020). The drawbacks of this chemical should be avoided and banned worldwide due to its high dermal absorption rate and toxic effects. However, only prescriptions are available in retail soaps containing 3 per cent hexachlorophene.

\section{Iodine and iodophors}

Iodine was known as an effective antiseptic in the 1800s, have been used for 150 years and less reactive than chlorine, iodine is rapidly bactericidal, fungicidal, virucidal and sporicidal (McDonnell and Russell, 1999). The mechanism of action of iodine, can penetrate easily into the bacteria cell wall and develop clusters with amino acids and unsaturated fatty acids that create disruptive protein synthesis and cell membranes (Edis et al., 2019). 
Nur Izyan Wan Azelee et al.

Table-5. Herbal used for the development of hand sanitizer disinfectant

\begin{tabular}{|c|c|c|c|c|c|}
\hline Product & $\begin{array}{c}\text { Herbal } \\
\text { formulations }\end{array}$ & $\begin{array}{c}\text { Others } \\
\text { chemical }\end{array}$ & Results & Conclusion & Reference \\
\hline \multicolumn{6}{|c|}{ Bacteriostatic } \\
\hline $\begin{array}{c}\text { Hand } \\
\text { sanitizer }\end{array}$ & $\begin{array}{l}\text { Eucalyptus, } \\
\text { Sadabahar } \\
\text { (Catharanthus } \\
\text { roseus) }\end{array}$ & Glycerine & $\begin{array}{l}\text { Antimicrobial result by } \\
\text { finger imprint technique } \\
\text { The microbial count } \\
\text { plunged from } 270 \text { to } 30 \text { in } \\
15 \text { min. }\end{array}$ & $\begin{array}{c}\text { Eucalyptus extract } \\
\text { has been shown to } \\
\text { have essential } \\
\text { antimicrobial } \\
\text { properties, hence the } \\
\text { hand sanitizer has } \\
\text { been formulated } \\
\text { with rose extract and } \\
\text { glycerine. }\end{array}$ & $\begin{array}{l}\text { (Singla and } \\
\text { Kamna, } \\
\text { 2019) }\end{array}$ \\
\hline $\begin{array}{l}\text { Gel Hand } \\
\text { Sanitizer }\end{array}$ & $\begin{array}{c}\text { Beluntas Leaf } \\
\text { (Pluchea indica L) }\end{array}$ & Glycerine & $\begin{array}{c}\text { Antimicrobial } \\
\text { result(inhibition zone) } \\
\text { S.aureus: between 9.5-14.67 } \\
\text { mm } \\
\text { Formula } 4 \text { with } 36 \% \text { leaf } \\
\text { extract } \\
\text { S.aureus }: 14.67 \mathrm{~mm}\end{array}$ & $\begin{array}{l}\text { Beluntas leaves } \\
\text { contain alkaloids, } \\
\text { tannins, flavonoids, } \\
\text { and essential oils. }\end{array}$ & $\begin{array}{c}\text { (Atikasari, } \\
\text { 2019) }\end{array}$ \\
\hline $\begin{array}{l}\text { Hand } \\
\text { sanitizer }\end{array}$ & Lotus seeds & $\begin{array}{l}\text { Glycerine, } \\
\text { TEA, } \\
\text { Methyl } \\
\text { paraben, } \\
\text { Carbopol } \\
940\end{array}$ & \begin{tabular}{l}
\multicolumn{2}{c}{ Antimicrobial } \\
result(inhibition zone) \\
S.aureus $: 12 \mathrm{~mm}$ \\
E.coli $\quad: 10 \mathrm{~mm}$
\end{tabular} & $\begin{array}{l}\text { Lotus seeds contain } \\
\text { phytochemicals as } \\
\text { antibacterial } \\
\text { properties such as } \\
\text { alkaloids, } \\
\text { flavonoids, steroids, } \\
\text { glycosides, } \\
\text { saponins, tannins, } \\
\text { and triterpenoids } \\
\end{array}$ & $\begin{array}{c}\text { (Cahyanin } \\
\text { gtyas et al., } \\
2019)\end{array}$ \\
\hline $\begin{array}{l}\text { Water- } \\
\text { based } \\
\text { herbal hand } \\
\text { sanitizer } \\
\text { gel }\end{array}$ & $\begin{array}{c}\text { Azadirachta indica, } \\
\text { Ocimum sanctum, } \\
\text { and Citrus limon } \\
\text { extracts }\end{array}$ & $\begin{array}{l}\text { Carbapol } \\
9400, \\
\text { EDTA, } \\
\text { Glycerine, } \\
\text { Perfume }\end{array}$ & $\begin{array}{l}\quad \begin{array}{l}\text { Antimicrobial } \\
\text { result(inhibition zone) }\end{array} \\
\text { Salmonella }: 3.7 \mathrm{~cm}=37 \mathrm{~mm} \\
\text { E. } \text { coli }: 3.6 \mathrm{~cm}=36 \mathrm{~mm} \\
\text { S.aureus }: 3.2 \mathrm{~cm}=32 \mathrm{~mm} \\
\text { C. } \text { Albicans }: 3.1 \mathrm{~cm}=31 \mathrm{~mm}\end{array}$ & $\begin{array}{l}\text { This research } \\
\text { suggests and } \\
\text { encourages the } \\
\text { introduction and use } \\
\text { of herbs in } \\
\text { formulations to } \\
\text { boost their efficacy. }\end{array}$ & $\begin{array}{l}\text { (Acharya } \\
\text { et al., } \\
\text { 2018) }\end{array}$ \\
\hline $\begin{array}{l}\text { Herbal } \\
\text { sanitizer }\end{array}$ & $\begin{array}{c}\text { Lemon sanitizer } \\
\text { Neem (Azadirachta } \\
\text { indica) }\end{array}$ & $\begin{array}{l}70 \% \\
\text { Isopropyl } \\
\text { alcohol, } \\
\text { Glycerol, } \\
\text { Rose } \\
\text { Water }\end{array}$ & $\begin{array}{c}\text { Antimicrobial } \\
\text { result(inhibition zone) } \\
\text { S.aureus : : } \\
2.4 \mathrm{~cm}=24 \mathrm{~mm} \\
\text { MRSA } \quad: 3.2 \\
\mathrm{~cm}=32 \mathrm{~mm} \\
\text { C. albicans : } 12 \mathrm{~cm}=12 \mathrm{~mm}\end{array}$ & $\begin{array}{l}\text { Lemon and lemon- } \\
\text { neem sanitizer can } \\
\text { be used as hand } \\
\text { sanitizers except for } \\
\text { neem sanitizer, } \\
\text { which must be } \\
\text { avoided due to its } \\
\text { bitter tastes. } \\
\text { Therefore, the } \\
\text { formulation was } \\
\text { suggested used for } \\
\text { floor cleaner, toilet } \\
\text { spray and antiseptic } \\
\text { for medical items }\end{array}$ & $\begin{array}{c}\text { (Patankar } \\
\text { and Nayna, } \\
\text { 2018) }\end{array}$ \\
\hline
\end{tabular}




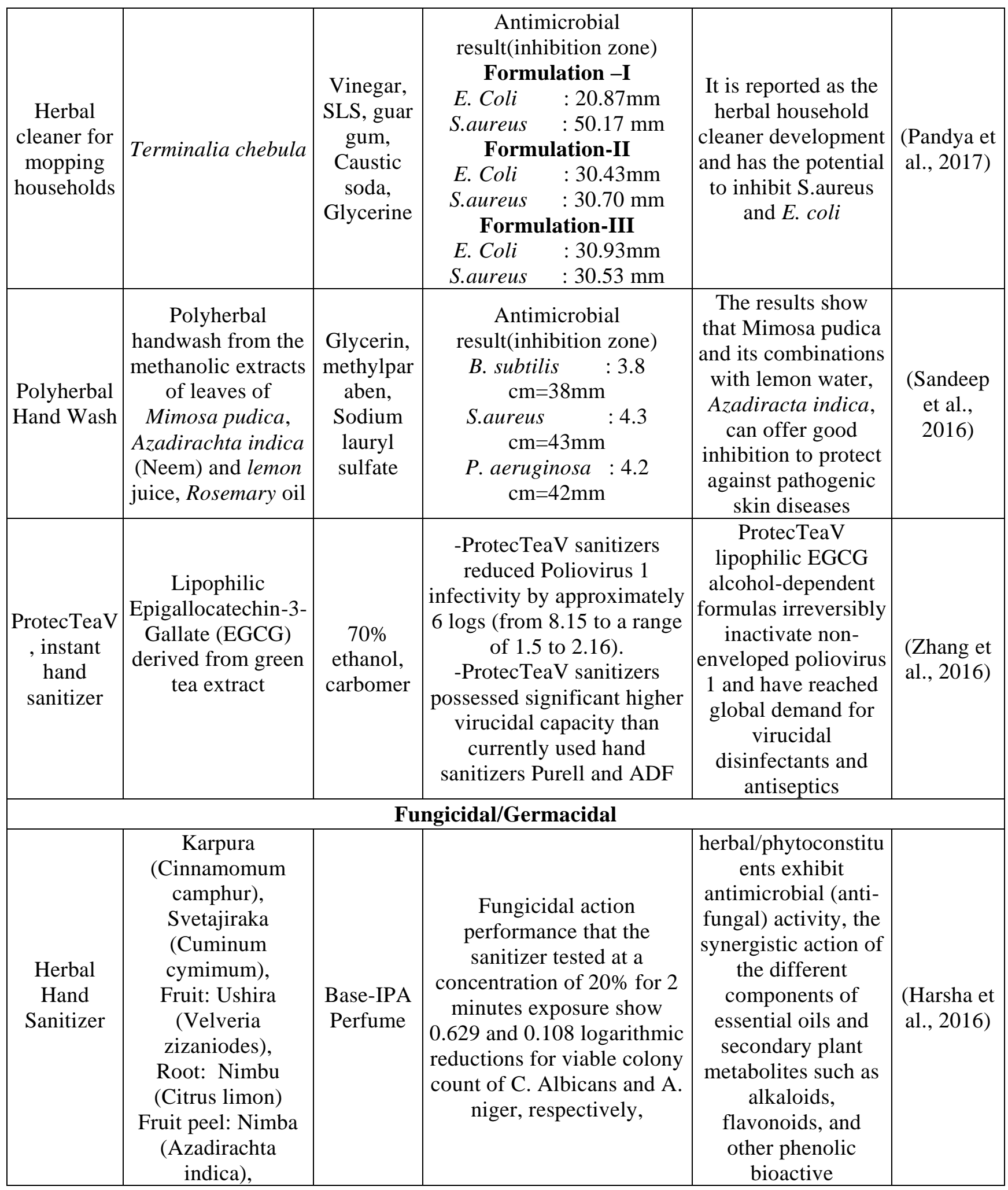




\begin{tabular}{|c|c|c|c|c|c|}
\hline $\begin{array}{c}\text { Herbal } \\
\text { Antiseptic } \\
\text { Detergent }\end{array}$ & $\begin{array}{l}\text { Toddalia Asiatica } \\
\text { commonly known } \\
\text { as Orange climber }\end{array}$ & $\begin{array}{c}\text { Sodium } \\
\text { lauryl } \\
\text { sulphates }\end{array}$ & 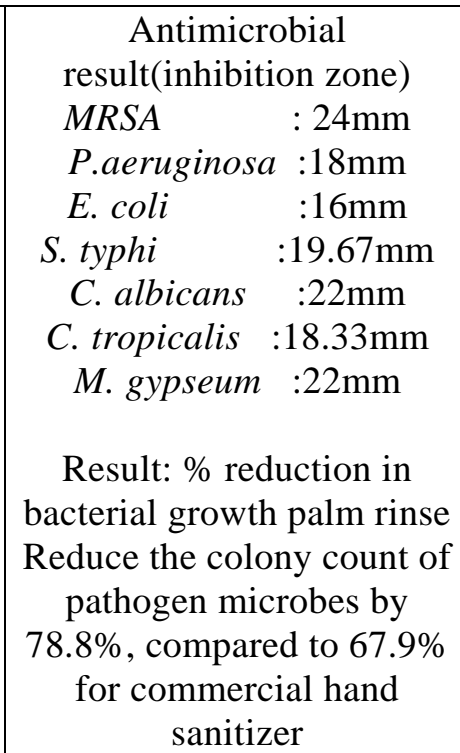 & $\begin{array}{l}\text { Herbal antiseptic } \\
\text { detergent is } \\
\text { developed as a } \\
\text { highly effective, } \\
\text { non-synthetic } \\
\text { germicidal agent. }\end{array}$ & $\begin{array}{l}\text { (Munyend } \\
\text { o and } \\
\text { Kiprop, } \\
\text { 2016) }\end{array}$ \\
\hline \multicolumn{6}{|c|}{ Others biocide ingredients } \\
\hline $\begin{array}{c}\text { Hand } \\
\text { sanitizer }\end{array}$ & $\begin{array}{c}\text { Pleurotus ostreatus } \\
\text { (Oyster Mushroom } \\
\text { Extract) }\end{array}$ & $\begin{array}{l}\text { Alcohol, } \\
\text { Glycerol, } \\
\text { sterile } \\
\text { water, }\end{array}$ & $\begin{array}{c}\text { For ethyl acetate and } \\
\text { ethanol extracts of Pleurotus } \\
\text { ostreatus mushroom, only } \\
\text { Staphylococcus aureus was } \\
\text { subject to a } 6.25 \mathrm{mg} / \mathrm{ml} \text { and } \\
12.5 \mathrm{mg} / \mathrm{ml} \text { (MIC), } \\
\text { respectively. }\end{array}$ & $\begin{array}{l}\text { The hand sanitizer } \\
\text { formulated with } \\
70 \% \text { alcohol and } \\
\text { mushroom extract } \\
\text { showed higher } \\
\text { antimicrobial } \\
\text { activity than the } \\
\text { other formulations. }\end{array}$ & $\begin{array}{c}\text { (Stanley et } \\
\text { al., 2017) }\end{array}$ \\
\hline
\end{tabular}

The disadvantages of iodine can cause skin irritation and discolouring, and iodophors have substituted it as the biocide in antiseptics. Iodophor is a mixture of iodine, iodide, or triiodide with surface-active agents that are non-toxic, non-staining, non irritating, stable in solution, effective as antiseptic, surface disinfectants and antimicrobial activity, including against acid-fast bacteria and hydrophilic virus. Iodine and iodophors are significant antibacterials to kill and inhibit gram-positive bacteria, gram-negative bacteria, mycobacteria, viruses, fungi, and spore-forming bacteria (Edis et al., 2019).

\section{Triclosan}

Triclosan is one of the ingredients in handwashing, mouthwashes, plastic coating material, a topical antiseptic, detergents, deodorants, shampoos, and lotions with various formulations varying from $0.4 \%$ $1 \%$ and alcohol (0.2\%-0.5\%) (WHO, 2009). Triclosan has a broad spectrum of antimicrobial behaviour in bacteria, funguses, and viruses, but show a weak practice to inhibit certain Gram- negative bacteria, particularly Pseudomonas Aeruginosa (Kim et al., 2015). Triclosan kills the microbes by damaging cell membranes. If the concentration is lower than $0.2 \%$, it acts as bacteriostatic and to attack the enoyl reductase needed by the living organism for fatty acid biosynthesis (Kim et al., 2015).

\section{Herbal hand sanitizers}

Natural herbs may be used as an alternative to chemicals to avoid disinfection by-products formation. Hundreds of herbal products to solve the problems were formulated and launched in the market. Plants with profound antimicrobial properties are commonly present in numerous secondary metabolites, and thus in conventional medicinal products have been widely used (Gomaa et al., 2019). Some plants have demonstrated activity for skin disinfection and incorporate secondary metabolite antimicrobial properties such as phenols, phenolic acids, flavones, flavonoids, flavonols, tannins, terpenoids, and essential oils are effective against bacteria, fungi, viruses, and protozoa (Anand 
et al., 2019). Table 5 provides comprehensive information on the study to develop the agent's properties through herbal as bioactive ingredients during the formulations and efficacy as a disinfectant product.

\section{Safety and precautions in sanitizers and disinfectants}

Infections triggered by many different aspects associated with structures and procedures of health care facility as well as to the human character that is habituated by education, political and economic limitations on systems and countries (Sallami, 2016). However, most infections are preventable, and one of the methods used is disinfectant or antiseptics. There are various types of antiseptics and disinfectants used for sterilization. However, these chemicals pose unwanted drawbacks if not used appropriately. Therefore, safety and precautions are both mandatory issues for the use of these chemicals. The World Health Organization (WHO) in (2009) has come out with guidelines on hand hygiene in health care for application in any state in which health care is delivered either to a patient or to a particular cluster of people. Antiseptic drugs and disinfectants remain extensively applied in a range of medical and occupational settings for the variability of topical and hard-surface applications (McDonnell and Russell, 1999). Currently, the alcohol-based antiseptic and disinfectant are the only acknowledged means for fast, worthy skin tolerability and efficiently deactivating a varied range of possibly dangerous microbe as well as viruses (WHO, 2014). WHO recommends alcohol-based hand rubs based on their efficacy, suitability in terms of resources, capacity to promote improve compliance, economic benefit, and minimization of hazards from adverse occasions.

Most alcohol-based hand antiseptics comprise either ethanol, isopropanol, ethanol, or benzalkonium chloride. According to the WHO (2020) guidelines, $60-80 \%$ of alcohol solutions are most effective, with higher concentration being compelling. Maier et al. (2015) studied developmental toxicity under relevant product use scenarios. In their work, they conclude that alcohol-based hand sanitizers by healthcare workers are safe even under hypothetical, worst-case conditions and that the risk of developmental or reproductive effects under such contact conditions is insignificantly small. Besides, no significant risk of developmental or reproductive toxicity is expected from potential occupational exposures from alcohol- based hand sanitizers or surgical scrubs based on the exposure margins and the dose-response characteristics of ethanol. Cartner et al. (2017) investigate the effect of ethanol, isopropanol, and npropanol on stratum corneum enzymes and keratinocytes in vitro with their effects on skin condition and function. They found that ethanolbased sanitizers are better tolerated by the skin, particularly in high-use settings, than other alcohols such as n-propanol or isopropanol. However, methanol must not be applied in the preparation of antiseptics or detergents product because oral, pulmonary and/or skin exposures can result in severe systemic toxicity and even deaths (Chan and Chan, 2018).

The need for regular hand hygiene throughout patient care may cause skin reactions (McGuckin and Govednik, 2017). There are two major types of skin reactions associated with hand hygiene, which are irritant contact dermatitis and allergic contact dermatitis. In addition to that, signs of allergic contact dermatitis can also array from minor and localized to severe and generalized. In its most severe condition, allergic contact dermatitis may relate to breathing distress and other symptoms of anaphylaxis (WHO, 2009). Skin that is impaired by repeated exposure to detergents may be more susceptible to irritation by all types of hand antisepsis formulations, including alcohol-based preparations (Lubbe et al., 2001). However, numerous reports confirm that alcohol-based formulations are well-tolerated and associated with better acceptability and tolerance than other hand hygiene products (Graham et al., 2005; Maier et al., 2015; WHO, 2009). Allergic reactions to antiseptic agents including didecyldimethylammonium chloride (Anderson et al., 2016), chlorhexidine (Abdallah, 2015), triclosan (Rundle et al., 2019), iodine (Rahimi and Lazarou, 2010), and alcohols (Cimiotti et al., 2003) are also reported. Nevertheless, allergic contact dermatitis related to alcohol-based hand rubs is very scarce. The usage of alcohol-based hand rubs is suggested rather than soap and water unless hands are noticeably soiled because hand rub products are better tolerated and cause in less dermatitis (Ellingson et al., 2014; WHO, 2009).

An alcohol-based hand rub might even reduce rather than escalate skin irritation after a hand wash due to a mechanical partial elimination of the detergent (Loffler and Kampf, 2008). Frequent and repeated use of hand hygiene products, particularly soaps and 
other detergents, is a significant cause of chronic irritant contact dermatitis among health care professionals. Some practices can increase the chances of skin irritation and should be eluded. For example, washing hands frequently with soap and water instantly before or after using an alcohol-based product is not only unnecessary but may lead to dermatitis. Accidental and intentional ingestion of alcohol-based preparations used for hand hygiene have been reported and may lead to acute, and in some cases, severe, alcohol intoxication. The number of new cases per year of intentional hand sanitizer ingestion significantly increased during the five years between 2005-2009 in the United States. Alcohols can be absorbed by inhalation and through intact skin, although the latter route through dermal uptake is very low (Fraise et al., 2013). Many studies assessed alcohol dermal absorption and inhalation following its application or spraying on skin. A study conducted by Hautemanière et al. (2013) assesses ethanol exposure during hygienic and surgical hand disinfection practices where they measured the ethanol concentrations the nose level of a wooden dummy and human volunteers. They assess the exposure at four different sequences $(N=10)$ reproducing hand rubs for a simple surgery, nursing care, intensive care and surgical scrub. Based on this study, they conclude that ethanol vapours released during hand disinfection were safe for the healthcare workers.

Besides ethanol, glycerol is also added as part of the formulation as an emollient to protect skin against dryness and dermatitis (Menegueti et al., 2019; Wan Azelee et al., 2019). Other emollients may be used for skincare, provided they are affordable, locally available, miscible (mixable) in water and alcohol, non-toxic, and hypoallergenic (WHO, 2009). Glycerol is usually chosen because it is safe and relatively inexpensive. Menegueti et al. (2019) suggested that $0.5 \%$ glycerol led to better ratings of skin tolerance and may offer the best balance between skin tolerance and antimicrobial efficacy. In term of product colourant, according to the latest WHO 2020 guidelines on hand rubs formulation, it can be incorporated to differentiate the hand rub from other fluids as long as such an additive is safe and compatible with the essential components of the hand rubs. However, the $\mathrm{H}_{2} \mathrm{O}_{2}$ in the hand rubs may tend to fade any colouring agent used and hence recommended for prior testing.

\section{New generation and future trends for} disinfectants and sanitizers

Utilization of hand washing or hand sanitizer is an essential practice to kill microbial contamination or infection. It is the standard practices that have been applied by people primarily who work in hospitals, laboratories or factories. Nowadays, this healthy trend is becoming more and more popular practice applied by many individuals, even at home. People have more awareness these days to take care of their health and cleanliness aspects in daily life activities, especially when the transmissible disease spread is becoming one of the threads to people worldwide. For example, the Ebola virus is one of the dangerous viruses and considered as an agent of emerging infections that may cause severe illness and hemorrhagic fever in humans and animals (Surani et al., 2018). Since the virus epidemic keeps on attacking human's life, people are starting to worry and take serious prevention steps. Moreover, during the epidemic or pandemic season, one of the essential kits that people are looking for is absolutely a disinfectant or sanitizer. Sanitizer is to remove the dirt and microbes like bacteria and virus from hands, thus reducing the possible transmission of diseases to other persons.

Since people nowadays are becoming more educated and conscious about the products purchased especially the healthcare products, they tend to check all the ingredients inside before starting to use them. They have their preference towards the products that they want to apply on their skins. Some individuals would prefer naturally based products and some would instead prefer the products that contain a specific chemical functional group that serves as a key element in resolving the problems. As for hand sanitizer, it can exist in two forms, alcohol-based sanitizer or alcohol-free sanitizer. The Covid-19 pandemic that hits all the population in the world these days had resulted in new ideas and innovations in developing the new-trend disinfectant or sanitizers. As a consequence, researchers have come out with new interesting ideas to replace the key element in the production of sanitizers. The idea varies from replacing ethanol with bio-materials compound and adding Aloe-Vera as a moisturizing agent to the extent of extracting the alcohol function from beverages (Osei-Asare et al., 2020). Adding some fragrant and herbs in the hand sanitizer formulation is also one of the current trends in this industry. For example, the formulation of sanitizer 
gel was recently carried out with addition of salam bark extract (Silvia et al., 2018).

Waterless sanitizer seems preferable and very useful nowadays. Since fingers are one part of the body that are considered dirty, hand sanitizer is one of the best solutions to keep them clean all the time especially after we came out from washrooms, after finished eating and after holding anything in public areas and transports. Moreover, hand sanitizers are always sold in small bottles and available in the pharmacies and healthcare stores, make it more practical to be purchased and carried anywhere. As a result, it is easier for individuals to practice a healthy lifestyle by keeping their hands clean all the time.

\section{Acknowledgment}

We thank the Institute of Bioproduct Development (IBD), Universiti Teknologi Malaysia for the support provided in completing this work.

Disclaimer: None.

Conflict of Interest: None.

Source of Funding: This work was supported by the Collaborative Research Grant UTM (Grant No. 4B438).

\section{References}

Abdallah C, 2015. Perioperative chlorhexidine allergy: Is it serious? J. Anaesthesiol. Clin. Pharmacol. 31(2): 152-154. doi:10.4103/09709185.155140.

Aboualizadeh E, Bumah VV, Masson-Meyers DS, Eells JT, Hirschmugl CJ and Enwemeka CS, 2017. Understanding the antimicrobial activity of selected disinfectants against methicillinresistant Staphylococcus aureus (MRSA). PLoS One. 12(10): e0186375. doi:10.1371/journal.pone.0186375.

Acharya SB, Ghosh S, Yadav G, Sharma K, Ghosh $S$ and Joshi S, 2018. Formulation, Evaluation and Antibacterial Efficiency of water-based herbal Hand Sanitizer Gel. bioRxiv. 373928. doi:10.1101/373928.

Aiello AE, Coulborn RM, Perez V and Larson EL, 2008. Effect of hand hygiene on infectious disease risk in the community setting: a metaanalysis. Am. J. Public Health. 98(8): 1372-
1381. doi:10.2105/ajph.2007.124610.

Akib NI, Wulandari IW, Suryani S and Hanari H, 2019. Formulasi gel hand sanitizer antibakteri kombinasi ekstrak rumput laut Eucheuma spinosum dan Eucheuma cottonii asal kepulauan Wakatobi Sulawesi. Jurnal Fish Protech. 2(2): 180-188.

Aldi Budi R and Nurniswati N, 2016. Adsorpsi Minyak Jelantah Menggunakan Karbon Aktif dan Serbuk Kopi pada Pembuatan Sabun Padat Ramah Lingkungan. Paper presented at the Seminar Nasional IPTEK Terapan 2016.

Anand U, Jacobo-Herrera N, Altemimi A and Lakhssassi N, 2019. A Comprehensive Review on Medicinal Plants as Antimicrobial Therapeutics: Potential Avenues of Biocompatible Drug Discovery. Metabolites. 9(11): 258.doi:10.3390/metabo9110258.

Anderson SE, Shane H, Long C, Lukomska E, Meade BJ and Marshall NB, 2016. Evaluation of the irritancy and hypersensitivity potential following topical application of didecyldimethylammonium chloride. J. Immunotoxicol. 13(4): 557-566. doi:10.3109/1547691x.2016.1140854.

Andriani Z, Fasya AG and Hanapy A, 2015. Antibacterial activity of the red Algae Eucheuma cottonii extract from Tanjung Coast, Sumenep Madura. Alchemy: J. Chem. 4: 93-100.

Ara K, Hama M, Akiba S, Koike K, Okisaka K, Hagura T, Kamiya T and Tomita F, 2006. Foot odor due to microbial metabolism and its control. Can. J. Microbiol. 52(4): 357-364. doi:10.1139/w05-130.

Atikasari L, 2019. Formulasi sediaan gel hand sanitizer ekstrak daun beluntas (Pluchea Indica L.) dan aktivitasnya terhadap Staphylococcus Aureus ATCC 25923 Secara Difusi Universitas Setia Budi Surakarta, Universitas Setia Budi Surakarta.

Berland C, 2019. United States Patent No. US Patent: P. A. Publication.

Cadnum JL, Jencson AL, O'Donnell MC, Flannery ER, Nerandzic MM and Donskey CJ, 2017. An Increase in Healthcare-Associated Clostridium difficile Infection Associated with Use of a Defective Peracetic Acid-Based Surface Disinfectant. Infect. Control Hosp. Epidemiol. 
38(3): 300-305. doi:10.1017/ice.2016.275.

Cahyaningtyas FD, Zhilla AU, Nora N and Amaria

A, 2019. Pemanfatan ekstrak biji teratai sebagai bahan aktif antibakteri untuk pembuatan hand sanitizer. Indonesian Chem. Appl. J. 3(1): 7-13.

Cartner T, Brand N, Tian K, Saud A, Carr T, Stapleton P, Lane ME and Rawlings AV, 2017. Effect of different alcohols on stratum corneum kallikrein 5 and phospholipase A2 together with epidermal keratinocytes and skin irritation. Int. J. Cosmet. Sci. 39(2): 188-196. doi:10.1111/ics.12364.

Chan APL and Chan TYK, 2018. Methanol as an Unlisted Ingredient in Supposedly AlcoholBased Hand Rub Can Pose Serious Health Risk. Int. J. Environ. Res. Public Health. 15(7). doi:10.3390/ijerph15071440.

Charbonneau DL, Ponte JM, and Kochanowski BA, 2000. A method of assessing the efficacy of hand sanitizers: use of real soil encountered in the food service industry. J. Food Prot. 63(4): 495-501. doi:10.4315/0362-028x63.4.495.

Choi D and Oh S, 2019. Removal of Chloroxylenol Disinfectant by an Activated Sludge Microbial Community. Microbes Environ. 34(2): 129. 135. doi:10.1264/jsme2.ME18124.

Cimiotti JP, Marmur ES, Nesin M, Hamlin-Cook P and Larson EL, 2003. Adverse reactions associated with an alcohol-based hand antiseptic among nurses in a neonatal intensive care unit. Am. J. Infect. Control. 31(1): 43-48. doi:10.1067/mic.2003.42.

Cook BWM, Cutts TA, Nikiforuk AM, Leung A, Kobasa D and Theriault SS, 2016. The Disinfection Characteristics of Ebola Virus Outbreak Variants. Sci. Rep. 6(1): 38293. doi:10.1038/srep38293.

Deshpande A, Mana TS, Cadnum JL, Jencson AC, Sitzlar B, Fertelli D, Hurless K, Kundrapu S, Sunkesula VCK and Donskey CJ, 2014. Evaluation of a sporicidal peracetic acid/hydrogen peroxide-based daily disinfectant cleaner. Infect. Control Hosp. Epidemiol. $\quad 35(11)$ : 1414-1416. doi:10.1086/678416.
Edis Z, Haj Bloukh S, Abu Sara H, Bhakhoa H, Rhyman L and Ramasami P, 2019. "Smart" Triiodide Compounds: Does Halogen Bonding Influence Antimicrobial Activities? Pathogens. 8(4): 182. doi: 110.3390/pathogens8040182.

Edmonds S, Dzyakanava V, and Macinga D, 2010. Efficacy of Hand Hygiene Products Against Pandemic H1N1 Influenza. Am. J. Infect. Control. 38(5): e132-e133. doi:10.1016/j.ajic.2010.04.179.

Ellingson K, Haas JP, Aiello AE, Kusek L, Maragakis LL, Olmsted RN, Perencivich E,Polgreen PM, Schweizer ML, Trexler P, VanAmringe $M$ and Yokoe DS, 2014. Strategies to prevent healthcare-associated infections through hand hygiene. Infect. Control Hosp. Epidemiol. 35(8): 937-960. doi:10.1086/677145.

Fisher J, 2003. Cleaning Procedures in the factory/ Types of Disinfectant. In Encyclopedia of Food Sciences and Nutrition, 2nd Edition. pp. 13821385.

Fraise AP, Jean-Yves M and Syed S, 2013. Russell, Hugo and Ayliffe's Principles and Practice of Disinfection, Preservation and Sterilization: Wiley-Blackwell.

Gallandat K, Wolfe MK and Lantagne D, 2017. Surface Cleaning and Disinfection: Efficacy Assessment of Four Chlorine Types Using Escherichia coli and the Ebola Surrogate Phi6. Environ. Sci. Technol. 51(8): 4624-4631. doi:10.1021/acs.est.6b06014.

Gerba CP, 2015. Quaternary Ammonium Biocides: Efficacy in Application. Appl. Environ. Microbiol. 81(2): 464-469. doi:410.1128/AEM.02633-02614.

Gold N and Avva U, 2020. Alcohol Sanitizer (Vol. Available from: https://www.ncbi.nlm.nih.gov/books/NBK513 254/. Treasure Island: StatPearls Publishing.

Gomaa SE, Yahayu M, Nurjayadi M, Dailin DJ and Hesham EE, 2019. Antimicrobial Compounds from Catharanthus roseus. Int. J. Sci. Res. 8: 113-121.

Gormley NJ, Bronstein AC, Rasimas JJ, Pao M, Wratney AT, Sun J, Austin HA and Suffredini $\mathrm{AF}, 2012$. The rising incidence of intentional ingestion of ethanol-containing hand 
sanitizers. Crit. Care Med. 40(1): 290-294. doi:10.1097/CCM.0b013e31822f09c0.

Graham M, Nixon R, Burrell LJ, Bolger C, Johnson PDR and Grayson ML, 2005. Low rates of cutaneous adverse reactions to alcohol-based hand hygiene solution during prolonged use in a large teaching hospital. Antimicrob. Agents Chemother. 49(10): 4404-4405. doi:10.1128/AAC.49.10.4404-4405.2005.

Harada Y, Lekcharoensuk P, Furuta $\mathrm{T}$ and Taniguchi T, 2015. Inactivation of Foot-andMouth Disease Virus by Commercially Available Disinfectants and Cleaners. Biocontrol Sci. 20(3): 205-208. doi:10.4265/bio.20.205

Harsha M, Baidyanath M, Chaithra CS and Vivekananda R, 2016. Evaluation of Fungicidal Activity of Herbal Hand Sanitizer. J. Res. Trad. Med. 2(3): 70-74.

Hashizume M, Aoki K, Ohno S, Kitaichi N, Yawata N, Gonzalez G, Nonaka H, Sato S and Takaoka A, 2019. Disinfectant potential in inactivation of epidemic keratoconjunctivitisrelated adenoviruses by potassium peroxymonosulfate. Eur. J. Ophthalmol. 1120672119891408. doi:10.1177/1120672119891408.

Hautemanière A, Cunat L, Ahmed-Lecheheb D, Hajjard F, Gerardin F, Morele $\mathrm{Y}$ and Hartemann P, 2013. Assessment of exposure to ethanol vapors released during use of AlcoholBased Hand Rubs by healthcare workers. J. Infect. Public Health. 6(1): 16-26. doi:10.1016/j.jiph.2012.09.015.

Iwasawa A, Niwano Y, Kohno M and Ayaki M, 2012. Virucidal activity of alcohol-based hand rub disinfectants. Biocontrol Sci. 17(1): 45-49. doi:10.4265/bio. 17.45 .

Ji W, Koepsel RR, Murata H, Zadan S, Campbell AS and Russell AJ, 2017. Bactericidal Specificity and Resistance Profile of Poly(Quaternary Ammonium) Polymers and Protein-Poly(Quaternary Ammonium) Conjugates. Biomacromolecules. 18(8): 2583 2593. doi:10.1021/acs.biomac.7b00705.

Joko S and Riyanta AB, 2019. Aktivitas antibakteri sediaan foot sanitizer spray yang mengandungi ekstrak biji kopi dan jahe. J. Parapemikir. 8(1): 47-50.
Joshi MG, Kamat DV and Kamat SD, 2008. Evaluation of herbal handwash formulation. Indian J. Nat. Prod. Resour. 7(5): 413-415.

Kampf G, 2018. Efficacy of ethanol against viruses in hand disinfection. J. Hosp. Infect. 98(4): 331-338. doi:10.1016/j.jhin.2017.08.025.

Kampf $G$ and Kramer A, 2004. Epidemiologic background of hand hygiene and evaluation of the most important agents for scrubs and rubs. Clin. Microbiol. Rev. 17(4): 863-893, table of contents. doi:10.1128/cmr.17.4.863-893.2004.

Kampf G, Ostermeyer C, Werner HP and Suchomel M, 2013. Efficacy of hand rubs with a low alcohol concentration listed as effective by a national hospital hygiene society in Europe. Antimicrob. Resist. Infect. Control. 2: 19-19. doi:10.1186/2047-2994-2-19.

Kampf G, Rudolf M, Labadie JC and Barrett SP, 2002. Spectrum of antimicrobial activity and user acceptability of the hand disinfectant agent Sterillium Gel. J. Hosp. Infect. 52(2): 141-147. doi:10.1053/jhin.2002.1281.

Kampf G, Todt D, Pfaender S and Steinmann E, 2020. Persistence of coronaviruses on inanimate surfaces and their inactivation with biocidal agents. J. Hosp. Infect. 104(3): 246251. doi: 10.1016/j.jhin.2020.01.022.

Khan MI, Abdulatef A, Shin JH, Baek JS, Kim MY and Kim JD, 2018. Antibacterial Effects against Various Strains of Gram Positive and Gram Negative Bacteria, a Comprehensive Study In Vitro and In Vivo. Evid. Based Complementary Altern. Med. 2018: 1-12.

Kim SA, Moon H, Lee K and Rhee MS, 2015. Bactericidal effects of triclosan in soap both in vitro and in vivo. J. Antimicrob. Chemother. 70(12): 3345-3352. doi:10.1093/jac/dkv275.

Liu M, Ou J, Zhang L, Shen X, Hong R, Ma H, Zhu $B$ and Fontaine RE, 2016. Protective Effect of Hand-Washing and Good Hygienic Habits Against Seasonal Influenza: A Case-Control Study. Medicine (Baltimore). 95(11): e3046. doi:10.1097/md.0000000000003046.

Loffler H and Kampf G, 2008. Hand disinfection: how irritant are alcohols? J. Hosp. Infect. 70 (Suppl 1): 44-48. doi:10.1016/s01956701(08)60010-9. 
Lubbe J, Ruffieux C, van Melle G and Perrenoud D, 2001. Irritancy of the skin disinfectant npropanol. Contact Derm. 45(4): 226-231. doi:10.1034/j.1600-0536.2001.450407.x.

Macinga DR, Sattar SA, Jaykus LA and Arbogast JW, 2008. Improved inactivation of nonenveloped enteric viruses and their surrogates by a novel alcohol-based hand sanitizer. Appl. Environ. Microbiol. 74(16): 5047-5052. doi:10.1128/aem.00487-08.

Maier A, Ovesen JL, Allen CL, York RG, Gadagbui BK, Kirman CR, Poet $\mathrm{T}$ and Quinones-Rivera A, 2015. Safety assessment for ethanol-based topical antiseptic use by health care workers: Evaluation of developmental toxicity potential. Regul. Toxicol. Pharmacol. 73(1): 248-264. doi:10.1016/j.yrtph.2015.07.015.

Martin ME and Pardiak EK, 2019. United States Patent No. United States Patent: B. I. T. (CA).

McDonnell G and Russell AD, 1999. Antiseptics and disinfectants: activity, action, and resistance. Clin. Microbiol. Rev. 12(1): 147179.

McGuckin M and Govednik J, 2017. Irritant Contact Dermatitis on Hands:Literature Review and Clinical Application. Am. J. Med. Qual. 32(1): 93-99. doi:10.1177/1062860615611228.

Meade E and Garvey M, 2018. Efficacy testing of novel chemical disinfectants on clinically relevant microbial pathogens. Am. J. Infect. Control. 46(1): 44-49. doi:10.1016/j.ajic.2017.07.001.

Menegueti MG, Laus AM, Ciol MA, AuxiliadoraMartins M, Basile-Filho A, Gir E, Piers D, Pittet D and Bellissimo-Rodrigues F, 2019. Glycerol content within the WHO ethanolbased handrub formulation: balancing tolerability with antimicrobial efficacy. Antimicrob. Resist. Infect Control. 8(109), doi:10.1186/s13756-019-0553-z.

Mitchell T, Dee DL, Phares CR, Lipman HB, Gould LH, Kutty P, Desai M, Guh A, Luliano AD, Silverman P, Siebold J, Armstrong GL, Swerdlow DL, Massoudi MS and Fishbein DB, 2011. Non-Pharmaceutical Interventions during an Outbreak of 2009 Pandemic Influenza A (H1N1) Virus Infection at a Large
Public University, April-May 2009. Clin. Infect. Dis. 52(Suppl 1): S138-S145. doi:10.1093/cid/ciq056.

Mujeeb F, Preeti B and Pathak N, 2014. Phytochemical Evaluation, Antimicrobial Activity, and Determination of Bioactive Components from Leaves of Aegle marmelos. Biomed. Res. Int. 2014: 1-11.

Munyendo WLL and Kiprop AK, 2016. Design, preparation and evaluation of germicidal Toddalia asiatica herbal antiseptic detergent. J. Appl. Pharm. Sci. 6(11): 100-104.

Nicolay CR, 2006. Hand hygiene: an evidencebased review for surgeons. Int. J. Surg. 4(1): 53-65. doi:10.1016/j.ijsu.2005.06.002.

Ogunsona EO, Muthuraj R, Ojogbo E, Valerio O and Mekonnen TH, 2020. Engineered nanomaterials for antimicrobial applications: A review. Appl. Mater. Today. 18: 100473. doi:10.1016/j.apmt.2019.100473.

Osei-Asare C, Eshun Oppong E, Apenteng JA, Adi-Dako O, Kumadoh D, Akosua AA and Ohemeng KA, 2020. Managing Vibrio cholerae with a local beverage: preparation of an affordable ethanol based hand sanitizer. Heliyon. 6(1): e03105. doi:10.1016/j.heliyon.2019.e03105.

Pandya U, Doshi A and Sahay NS, 2017. Development of herbal disinfectants formulation for mopping households and its antibacterial activity. Nat. Prod. Res. 31(22): 2665-2668. doi:10.1080/14786419.2017.1283491.

Patankar RS and Nayna C, 2018. Formulation of herbal sanitizers and determining their antimicrobial activities against skin pathogens. Int. J. Innov. 3(8): 169-177.

Pelczar M J, Chan ECS and Krieg NR, 1993. Microbiology: Concepts and Applications: McGraw-Hill.

Qian J, 2019. United States: U. S. Patent. USPTO, Alexandria, Virginia, USA.

Rabie T and Curtis V, 2006. Handwashing and risk of respiratory infections: a quantitative systematic review. Trop. Med. Int. Health. 11(3): 258-267. doi:10.1111/j.13653156.2006.01568.x. 
Rahimi S and Lazarou G, 2010. Late-onset allergic reaction to povidone-iodine resulting in vulvar edema and urinary retention. Obstet. Gynecol. $116 \quad$ (Suppl 2): 562-564. doi:10.1097/AOG.0b013e3181e91fa3.

Revellame ED and Holmes WE, 2019. United States Patent No. US Patent: U. S. P. A. Publication.

Riool M, 2017. Novel antibacterial strategies to combat biomaterial-associated infection. (PhD $\mathrm{PhD}$ Thesis), University of Amsterdam, Amsterdam.

Riyanta AB and Febriyanti R, 2018. Pengaruh kombinasi ekstrak biji kopi dan rimpang jahe terhadap sifat fisik sediaan foot sanitizer spray. Jurnal Para Pemikir. 7(2): 247-251.

Romanowski EG, Yates KA, Shanks RMQ and Kowalski RP, 2019. Benzalkonium Chloride Demonstrates Concentration-Dependent Antiviral Activity Against Adenovirus In Vitro. J. Ocul. Pharmacol. Ther. 35(5): 311314. doi:10.1089/jop.2018.0145.

Rundle CW, Hu S, Presley CL and Dunnick CA, 2019. Triclosan and Its Alternatives in Antibacterial Soaps. Dermatitis. 30(6): 352357. doi: 310.1097/DER.0000000000000519.

Rutala WA and Weber DJ, 2019. Best practices for disinfection of noncritical environmental surfaces and equipment in health care facilities: A bundle approach. Am. J. Infect. Control. 47s: A96-a105. doi:10.1016/j.ajic.2019.01.014.

Sallami ZA, 2016. Assessment of Hand Hygiene Attitude, Knowledge and Practice among Health Science Students in Aden University. J. Biosci. Med. 4: 25-32.

Sandeep D, Narayana CR, Prashant N, Aliss M and Indira $\mathrm{G}, 2016$. Formulations of antimicrobial polyherbal hand wash. Res. J. Pharm. Technol. 9(7): 864-866.

Saradhajyothi K and Subbarao B, 2011. Antibacterial Potential of the Extracts of the Leaves of Azadirachta indica Linn. Not. Sci. Biol. 3(1): 65-69. doi:10.15835/nsb315470.

Saxena M, Jyoti S, Rajeev N, Dharmendra S and Abhishek G, 2013. Phytochemistry of medicinal plants. J. Pharmacog. Phytother. 1(6): 168-182.

Siddharta A, Pfaender S, Vielle NJ, Dijkman R, Friesland M, Becker B, Yang W, Engelmann
M, Todt D, Windisch MP, Brill FH, Steinmann J, Steinmann J, Becker S, Alves MP, Pietschmann T, Eickmann M, Theil V and Steinmann E, 2017. Virucidal Activity of World Health Organization-Recommended Formulations Against Enveloped Viruses, Including Zika, Ebola, and Emerging Coronaviruses. J. Infect. Dis. 215(6): 902-906. doi:10.1093/infdis/jix046.

Silvia S, Nurul Isti A and Delly Chipta L, 2018. Formulation and Effecttiveness of a Hand Sanitizer Gel Produced using Salam Bark Extract. Int. J. Appl. Pharm. 10(Special Issue 1), doi:10.22159/ijap.2018.v10s1.48.

Singla D and Kamna S, 2019. Formulation of an herbal substitute for chemical sanitizer and its evaluation for antimicrobial efficiency. Int. J. Chemtech. Res. 12(3): 114-120.

Smith LS, Rastogi VK and Wallace L, 2016. Adaptive mechanisms underlying microbial resistance to disinfectants. United States: US Army Rdecom.

Stanley CN, Alobari VB and Ezealisiji KM, 2017. Formulation and Evaluation of the Effectiveness of a Novel Hand Sanitizer using Pleurotus ostreatus Oyster Mushroom Extract. Int. J. Pharm. Sci. Rev. Res. 6: 7-15.

Steinmann J, Becker B, Bischoff B, Paulmann D, Friesland M, Pietschmann T, Steinmann J and Steinmann E, 2010. Virucidal activity of 2 alcohol-based formulations proposed as hand rubs by\&\#xa0; the World Health Organization. Am. J. Infect. Control. 38(1): 66-68. doi:10.1016/j.ajic.2009.07.009.

Surani A, Marfatia YS, Pal A and Shah R, 2018. Ebola virus: An emerging sexually transmissible infection pathogen. Indian J. Sex. Transm. Dis. AIDS. 39(1): 65-67. doi:10.4103/ijstd.IJSTD_21_18.

van Engelenburg FA, Terpstra FG, Schuitemaker $\mathrm{H}$ and Moorer WR, 2002. The virucidal spectrum of a high concentration alcohol mixture. J. Hosp. Infect. 51(2): 121-125. doi:10.1053/jhin.2002.1211.

Wan Azelee NI, Ramli ANM, Abdul Manas NH, Salamun N, Che Man R and Hesham EE, 2019. Glycerol in food, cosmetics, and pharmaceutical industries: Basics and new applications. Int. J. Sci. Res. 8: 553-558. 
Weber DJ, Rutala WA and Sickbert-Bennett EE, 2007. Outbreaks Associated with Contaminated Antiseptics and Disinfectants. Antimicrob. Agents Chemother. 51(12): 4217. doi:10.1128/AAC.00138-07.

WHO, 2009. 11, Review of preparations used for hand hygiene. In WHO Guidelines on Hand Hygiene in Health Care: First Global Patient Safety Challenge Clean Care Is Safer Care. Geneva: World Health Organization, Geneva, Switzerland.

WHO, 2014. Infection prevention and control of epidemic-and pandemic prone acute respiratory infections in health care. World Health Organisation, Geneva, Switzerland.

WHO, 2020. WHO-recommended handrub formulations. World Health Organisation, Geneva, Switzerland.

Will FIII and Varsel C, 2020. Spectrophotometric Determination of Hexachlorophene and Zinc Phenolsulfonate in Aerosol Deodorants. J. Assoc. Off. Anal. Chem. 49(5): 949-954. doi:10.1093/jaoac/49.5.949.

WoIff MH, Schmitt J, Rahaus M and König A, 2001. Hepatitis A virus: a test method for virucidal activity. J. Hosp. Infect. 48: S18-S22. doi:10.1016/S0195-6701(01)90007-6.

Wong HC, Liao R, Hsu P and Tang CT, 2018. Molecular response of Vibrio parahaemolyticus to the sanitizer peracetic acid. Int. J. Food Microbiol. 286: 139-147. doi:10.1016/j.ijfoodmicro.2018.08.008.

Yost LJ, Rodricks JD, Turnbull D, DeLeo PC, Nash JF, Quinones-Rivera A and Carlson PA, 2016. Human health risk assessment of chloroxylenol in liquid hand soap and dishwashing soap used by consumers and health-care professionals. Regul. Toxicol.
Pharmacol. 80: 116-124. doi:10.1016/j.yrtph.2016.06.003.

Zandiyeh $\mathrm{M}$ and Roshanaei G, 2015. Effectiveness of three surgical alcohol-based hand rubs on skin flora. Iran. J. Nurs. Midwifery Res. 20(2): 221-225.

Zhang Q, Qingyu Y, Wanqi Y, Kailang W, Jianguo W, Douglas D and Stephen H, 2016. Virucidal Capacity of Novel ProtecTeaV Sanitizer Formulations Containing Lipophilic Epigallocatechin-3-Gallate (EGCG). J. Antivir. Antiretrovir. Res. Ther. 1: 002.

\section{Contribution of Authors}

Azelee NIW: Conceptualized the whole outline of the review article, manuscript writing and final proofreading

El-Enshasy H: Conceptualized the whole outline of the review article, manuscript writing and final proofreading Dailin DJ: Contributed ideas on the aspect of microorganism (bacteria and viruses) and manuscript writing

Manas NHA: Contributed ideas on the aspect of microorganism (bacteria and viruses) and manuscript writing

Malek RA: Contributed ideas on the aspect of microorganism (bacteria and viruses) and manuscript writing

Mokhter MA: Contributed ideas on the chemistry aspect of developing hand sanitizers and detergents and wrote part of the manuscript Salamun N: Contributed ideas on the chemistry aspect of developing hand sanitizers and detergents and wrote part of the manuscript Rahman RA: Proofread and gave comments to improve the quality of the manuscript 